\title{
Response to "The CUBE Technique: Continuous Ultrasound- Guided Breast Excision," Published in August 2014 by Tummel et al. Amsterdam, 28th January 2015
}

\author{
N. M. A. Krekel, MD, PhD, M. H. Haloua, MD, PhD, J. H. Volders, MD, S. Meijer, MD, PhD, M. P. van den Tol, \\ MD, PhD, and On Behalf of Our Study Group
}

Department of Surgical Oncology, VU University Medical Center, Amsterdam, The Netherlands

\section{TO THE EDITOR}

We read the article "The CUBE technique: continuous ultrasound-guided breast excision," published in August 2014 by Tummel et al. ${ }^{1}$ We congratulate the authors on their study and the positive results concerning intraoperative ultrasonography for breast cancer surgery. However, if the authors had performed a review of the literature on this subject, they would have realized that the described technique is actually not as "novel" as they opine. Over the past years, our study group has extensively published on this subject, resulting in a multicenter, randomized controlled trial including 134 patients. $^{2}$ Although the term "CUBE" is indeed novel, the technique itself is an exact copy of the technique we-among other authors-have repeatedly described. ${ }^{3-7}$ Needless to say, it would have been appropriate for the authors to refer to these studies while presenting their results, and we are somewhat disappointed that the journal did not revise the literature list on behalf of the authors. We recommend that the authors repeat our randomized controlled trial on use of intraoperative ultrasound, so we can convince all surgical oncologists to use this excellent technique in the operating theater. It would be highly appreciated if the authors could respond to our letter, and we await their reply.

\section{REFERENCES}

1. Tummel E, Betzold R, Gallagher K, Klimberg VS. The CUBE technique: continuous ultrasound-guided breast excision. Ann. Surg. Oncol. 2014 21:3354-65.

2. Krekel NM, Haloua MH, Lopes Cardozo AM, de Wit RH, Bosch AM, de Widt-Levert LM, et al. Intraoperative ultrasound guidance for palpable breast cancer excision (COBALT trial): a multicentre, randomised controlled trial. Lancet Oncol. 2013 14:48-54.

3. Krekel NM, Lopes Cardozo AM, Muller S, Bergers E, Meijer S, van den Tol MP. Optimising surgical accuracy in palpable breast cancer with intra-operative breast ultrasound-feasibility and surgeons' learning curve. Eur. J. Surg. Oncol. 2011 37:1044-50.

4. Krekel NMA, Zonderhuis BM, Stockmann HBAC, Schreurs WH, van der Veen H, de Lange de Klerk ESM, et al. A comparison of three methods for nonpalpable breast cancer excision. Eur. J. Surg. Oncol. 2011 37:109-15.

5. Rahusen FD, Taets van Amerongen AH, van Diest PJ, Borgstein PJ, Bleichrodt RP, Meijer S. Ultrasound-guided lumpectomy of nonpalpable breast cancers: a feasibility study looking at the accuracy of obtained margins. J. Surg. Oncol. 1999 72:72-76.

6. Moore MM, Whitney LA, Cerilli L, Imbrie JZ, Bunch M, Simpson $\mathrm{VB}$, et al. Intraoperative ultrasound is associated with clear lumpectomy margins for palpable infiltrating ductal breast cancer. Ann. Surg. 2001 233:761-68.

7. Haloua MH, Krekel NM, Coupe VM, Bosmans JE, Lopes Cardozo $\mathrm{AM}$, Meijer S, et al. Ultrasound-guided surgery for palpable breast cancer is cost-saving: results of a cost-benefit analysis. Breast. 2013 22:238-43.
(C) Society of Surgical Oncology 2017

First Received: 10 October 2017;

Published Online: 7 November 2017

N. M. A. Krekel, MD, PhD

e-mail:n.krekel@vumc.nl 